\title{
Diasporas and conflict: distance, contiguity and spheres of engagement
}

\author{
Nicholas Van Hear and Robin Cohen
}

accepted for publication by Oxford Development Studies 


\section{Diasporas and conflict: distance, contiguity and spheres of engagement}

NICHOLAS VAN HEAR AND ROBIN COHEN

ABSTRACT Diasporas are now well-established players in the global political economy, yet their role in conflict and post conflict settings remains controversial. Diasporas have variously been described as war-mongers, peace-builders, or ambivalent in their influence on conflict. We suggest that this variety of characterizations might be explained by disaggregating forms of diaspora engagement and the public and private spaces in which they occur into three 'spheres of engagement'. We then go on to consider two variants of conflict-related diasporas: 'distant diasporas', alluding particularly to Sri Lanka, Afghanistan and Somalia, and 'contiguous diasporas', referring mainly to the Russian-speaking peoples in the former Soviet Union, but also to groups like the Kurds spread across several nationstates. We show that different forms and levels of engagement generate varying levels of demand on diasporan households. Differences of wealth, resources, social capital and class also influence the capacity of diasporas to engage in conflict and post-conflict roles.

In the 1990s and early 2000s the prevalence of high profile conflicts, as well as the intractability of many neglected ones, led to a greater appreciation among humanitarian and development agencies that societies in conflict needed to brought into the fold of reconstruction, recovery and development. Thanks in part to the work of Fitzgerald and Stewart (among others), analysts and policy makers increasingly came to recognise that violent conflict and displacement were not aberrant conditions affecting just a few wayward, peripheral states, but were common to large swathes of the developing world. To the extent that diasporas were considered in this context, they were seen largely as a negative force, fomenting or sustaining violence and insurgency. A much-cited view in this vein was advanced by Collier (2000: 14), who we quote below: 
Diasporas sometimes harbour rather romanticised attachments to their group of origin and may nurse grievances as a form of asserting continued belonging. They are much richer than the people in their country of origin and so can afford to finance vengeance. Above all, they do not have to suffer any of the awful consequences of renewed conflict because they are not living in the country. Hence, they are a ready market for rebel groups touting vengeance and so are a source of finance for renewed conflict.

Now a more discriminating view prevails. Over the last decade or so, scholars spanning a number of disciplines -- from political science and political economy to anthropology -- have shown that the influence of diasporas is rarely consistent across whole groups and often shifts over time: sometimes it is negative and sometimes positive, with different parts of diasporas moving between roles as 'war-mongers' and 'peace-wreckers' fomenting conflict and spoiling the chances of reconciliation, or as 'peace-makers' and 'peace-builders', assisting with relief and recovery during and after conflict (Adamson 2002, 2005, 2012, 2013; Van Hear, 2002, 2006a, 2006b; Shain and Barth, 2003; Sheffer, 2003; Orjuela, 2003; Smith and Stares, 2007; Kapur 2007; Lyons, 2007; Cochrane et al, 2009; Brinkerhoff, 2011; Koinova, 2012; Harpviken and Lischer, 2013). Notwithstanding the variety of views, perhaps the most significant implicit realisation has been that while conflict undermines development by destroying assets and resources and by killing and displacing people, displacement itself contributes to the formation of diasporas, which can themselves in time constitute a resource - positive or negative -- for conflict-ridden societies. As we suggest below, our contribution to this debate offers a way to understand this somewhat convoluted reputation that diasporas have earned for themselves in conflict and postconflict settings by disaggregating the ways and spaces in which they engage.

Before we unfold our argument, we first indicate the ways in which Valpy Fitzgerald has helped to shape understanding of conflict within the context of development, and to some degree the place of diasporas in conflicts. In partnership with Frances Stewart, Valpy Fitzgerald's work on conflict and development spans two related projects. The first of these generated two volumes on War and underdevelopment: the economic and social consequences of conflict (Stewart, Fitzgerald and associates, 2000), based on research 
conducted in the second half of the 1990s, a boom time both for conflict in the wake of the end of the Cold War and for research on $\mathrm{it}^{1}$. The first, synoptic, volume investigated economic and social consequences of conflict at the macro-, meso- and micro-levels, with the object of identifying both the direct and indirect human and economic costs of conflict, giving a new slant on reductions in entitlements in conflict settings. The second volume set a number of case studies - on Afghanistan, Mozambique, Nicaragua, Sierra Leone, Sri Lanka, Sudan and Uganda - within this framework. The two volumes reflected a spate of interest in and publications on conflict, sparked in part by a rash of conflicts in the immediate postCold War period, including influential work by Richards (1996), Duffield (1996, 1998, 2001, 2007), Keen (1998), Reno (1998), Kaldor (1999), Collier (2000) and Collier and Hoeffler (2004). Most of these authors were anthropologists, sociologists and political scientists. The exception was the work by Collier, quoted above, an Oxford economist with influence in the World Bank. However, his conclusions were based on dubious assumptions and methods. ${ }^{2}$ It took Fitzgerald and Stewart's book to provide a firmer and more substantial economic analysis of war and its effects.

Analysis by reputable economists gave an imprimatur of respectability to the idea that conflict was worth investigating in the context of development: this may seem obvious now, but it was not so then - until the work by Fitzgerald and Stewart appeared. Diasporas did not figure prominently in their analysis, but they did appear in the follow-up book Globalisation, violent conflict and self-determination (Fitzgerald, Stewart and Venugopal, 2006), particularly in the contribution by Venugopal on 'the global dimensions of conflict', which addressed the Sri Lankan case. It would perhaps be fair to say that in this corpus of conflict-related work diasporas appear largely as 'war-mongers', particularly insofar as they provide aid, remittances, weapons and political support to dissident, usually separatist,

\footnotetext{
${ }^{1}$ Nicholas Van Hear was at the time doing related work at the Refugee Studies Programme (as it was then), and there was some (though arguably not enough) crossover between his work and that of Valpy Fitzgerald and Frances Stewart.

${ }^{2}$ For example, Collier and Hoeffler (2004) concluded that having a large diaspora in a rich country outside the homeland substantially increased the chances of the resumption of civil war. Distinctions between diaspora, ethnicity and minority group were ignored while, implausibly, the size of a given ethnic group in the US was used as a proxy for diaspora size worldwide. This is generally an unreliable assumption, but one that becomes very odd in the case of contiguous diasporas, discussed below.
} 
groups. We cover a wider range of outcomes. But first we set out our conceptual framework for considering the place of diasporas in conflict settings.

\section{Spheres of diaspora engagement in conflict settings}

We suggest that the variety of characterizations of the role of diasporas in conflict might be explained by differentiating forms of diaspora engagement and the public and private spaces in which they occur. We distinguish three spheres of engagement: the largely private and personal sphere of the household and the extended family; the more public sphere of the 'known community', by which is meant collectivities of people that know each other or know of each other; and the largely public sphere of the 'imagined community', which includes the transnational political field, among other arenas ${ }^{3}$. By disaggregating 'diaspora engagement' we tease out different orders of connection and disconnection between the diaspora and those at home. In particular, we reveal the conditions and circumstances that can generate common ground as well as rendering them at odds with one another in conflict settings. Our three spheres of diaspora engagement, elaborated below, feature different combinations of the private and public.

The household/extended family sphere. Engagement in the household and extended family is largely personal and private, and is likely to be the most sustained of the three spheres not surprisingly since it involves basic, core relationships of kith and kin. The most common, well-known, and tangible form of engagement is sending remittances to assist nuclear and extended family members to survive and cope, especially in conflict settings or other circumstances of distress. The money sent may be used for everyday needs, including housing, provisions, schooling, health-care, and sometimes to help people escape zones of danger, which can involve paying an agent to organise migration abroad. Besides such transfers in cash and kind, diaspora members may participate in life-course events such as births, naming ceremonies, marriages and funerals either 'virtually' or in person. Such

\footnotetext{
${ }^{3}$ This conceptual framework was developed and elaborated by Nicholas Van Hear to structure the project he leads on Diaspora engagement in war-torn societies. The project is part of the Oxford Diasporas Programme (ODP) led by Robin Cohen, who has added material on contiguous diasporas for this paper. The ODP is funded by the Leverhulme Trust.
} 
engagement may involve visits and other physical encounters, but in conflict settings online connections and telephony often necessarily replace face-to face physical connection.

The known community sphere. Engagement in the 'known community sphere' takes place in spaces where one lives or has lived, among people one knows or knows of. It is the sphere of encounters in schools, neighbourhoods, workplaces, markets and shops, places of religious observance, associations and clubs, sports and leisure venues and during cultural activity. It is the realm of associational life: of associations based on residence, ethnicity or religion, education, mutual aid and welfare bodies, community-based and civil society organizations. Home town and home village associations and in particular old school associations have been important forms of diasporic organisation and engagement. Language classes and re-engaging with shared cultural practices like music, dance and cuisine have also become prominent features of the community sphere. Although their influence may decline in conflict contexts as time passes and connections grow weaker, engagement in these and other forms of associational life may also expand with the use of social media and enhanced possibilities of travel. Transfers to collectivities wider than households and extended families can also be included here: examples include donations made in temples, churches or mosques for relief in the home country; the home town association or old school association that collects funds to rebuild a school, equip a hospital, or refurbish a library; collections by diaspora-based welfare organisations to provide relief for the victims of conflict; or, in a more menacing direction, the collections by supporters of insurgent groups for funds to buy weapons or otherwise support insurgency. These transfers, for more public or collective purposes, are somewhat different in nature from the more private remittances described above in the first, household or extended family sphere. In aggregate they are also probably smaller in scale than private remittances, but, importantly, they also have bonding functions. In conflict settings the significance of such collective transfers goes beyond their immediate economic and material effects, since they can help recreate or repair the social fabric shredded by years of conflict, not least by helping to re-establish social linkages ruptured during war, and re-building trust and confidence. 
The imagined community. In coining the notion 'the imagined community', Benedict Anderson referred to the nation, the largest unit, he suggested, with which one has an affinity without necessarily knowing its members personally (Anderson, 1983/1991). However, in his published lecture on long-distance nationalism, Anderson (1992) recognised that the nation can spill out of its state's borders. He concluded his lecture with the emblematic case of a Sikh businessman in Toronto, who valued his own quiet life, but bankrolled protagonists trying to create a new homeland, Khalistan, by force. Implicitly, Anderson conceded that there is no logical reason why the imagined community should not be widened beyond the nation, to co-nationals. We add that it can be widened also to other collectivities such as co-religionists and co-ethnics - and perhaps also to certain classes, generations and social movements (Sklair, 2000; Cohen and Rai, 2000). This is the sphere in which such allegiances are articulated and contested - indeed some argue convincingly that it is through such mobilization and contestation that diasporas come into being (Sökefeld, 2006). Engagement here includes membership of or involvement in political parties and movements, and support for insurgent, oppositional and sometimes loyalist groups. It might involve public demonstrations or lobbying politicians or other influential people in the host country, in the homeland or in the international arena. In recent years, it has increasingly taken the form of engagement in political, social or cultural debate in cyberspace. This sphere is usually the most volatile of the three and perhaps the least pervasive in terms of general and sustained participation: it requires greater degrees of social mobilisation than do the more routine activities of the household and community spheres. To the mobilization within the diaspora needs to be added the initiatives taken by those state actors who imagine a nation beyond the state's borders. They may seek to connect to their nationals abroad, encourage diasporic forms of citizenship and loyalty, and intervene, perhaps militarily, to protect 'their' diasporas (Gamlen 2014). This is particular salient, as we will demonstrate, in the case of contiguous diasporas.

These three spheres are analytical categories and there is of course overlap and interplay among them: for example, what happens in the imagined community sphere may shape what is possible in the known community and household spheres - and vice versa, family allegiances may shape 'known community' involvement and engagement in the 'imagined 
community' sphere. There are also tensions among the different spheres - diaspora members may find themselves pulled between obligations to their own family in the host country, to their own community in the host country, to those in the wider diaspora, to those left in the conflict-ridden homeland, and to the wider political struggle in the homeland. Their capacity to meet these different calls varies according to their resources and social position, and shifts over time. Likewise, those at home may view diaspora engagement in the different spheres as congruent with or inimical to their interests, at times prioritising help in the household sphere and at others welcoming - or being uncomfortable with - political mobilisation in the imagined community sphere. We suggest that some of these and other apparent contradictions and paradoxes of diaspora engagement may be explained and better understood if such engagement is disaggregated in the way we propose.

A distinction should next be drawn between the capacity and the desire to engage in conflict settings (Al Ali, Black and Koser, 2001). Capacity to engage is shaped, among other things, by security of status, having an income above subsistence level, having the freedom to speak out, and developing social competence and political literacy - and connecting to civil society by such means as lobbying, campaigning, speaking in public, writing leaflets and drawing up funding proposals. The desire to engage may be shaped by personal or private motivations, such as the imperative to protect one's family, kin or friends; by wider humanitarian concerns for the community, society or nation; and by stanch political motivation, driven perhaps by ethno-nationalism.

At the more macro level, determinants of engagement include the course of a given conflict, the way in which war may have ended, and the nature of the 'post-conflict' society. The outcomes of conflict can include:

- $\quad$ Stalemate (Palestine, Somalia, Afghanistan, Sri Lanka pre-2009, parts of central and eastern Africa, perhaps eastern Ukraine and other cases of 'frozen conflict')

- $\quad$ Negotiated peace/settlement (Liberia, the Balkans)

- Military victory by one side: a 'victor's peace' (Sri Lanka post-2009, Crimea) 
Each conflict may feature several of these conditions over time. In the case of Sri Lanka, military stalemate obtained during most of the near three decades of war, but there was a negotiated peace during a ceasefire in 2002-04, and then outright military victory by the government side in 2009 leading to a 'victor's peace'.

Diasporas may engage in a post-war society if there is a negotiated peace or settlement; some of the diaspora may indeed even return to participate in the post-war administration or government, as in the case of Liberia and parts of the Balkans. Under certain conditions they may also do so if there is stalemate (for example, Somalia, Palestine, Afghanistan). However the diaspora is much less likely to engage if there is an outright military victory (a 'victor's peace') and the diaspora is on the losing side, as in the case of Tamils from Sri Lanka. They are much less likely to involve themselves in state rebuilding and will resist subscribing to the victor's 'imagined community'; they are likely to maintain their own vision or imagined community - hence the persistence of a vision of Tamil Eelam among many in the Tamil diaspora, as we will see below.

The nature of post-war society will also shape the propensity of the diaspora to engage. Hence a 'liberal peace' (Duffield, 2001), with democratic institutions and perhaps a liberalised economy, will likely be more attractive from the diaspora point of view than a victor's peace with an authoritarian and/or majoritarian regime in power. The balance or mix of state, market and civil society will also influence diaspora engagement, as will the balance of public goods and welfare, and the penetration of the market or commodification. These outcomes and determinants of course shape the political 'opportunity structure' (Adamson, 2002, 2005) for diaspora engagement.

Kaldor (2001), Van Hear (2006a, 2009) and Harpviken (2008), among others, have drawn the distinction between 'near diasporas' in territories neighbouring the country in conflict such as Pakistan and Iran in the case of Afghanistan, and Kenya and Ethiopia in the case of Somalia - and 'wider diasporas' dispersed much further afield, often in other continents. Here we cast the distinction slightly differently, differentiating between what we call distant diasporas, originating from conflict-affected territories like Sri Lanka, Afghanistan and Somalia, and what we term contiguous diasporas, such as the people divided by borders 
introduced among the successor states of the former Soviet bloc, but also groups like the Kurds spread across several nation-states in the same neighbourhood. We have selected two paradigmatic cases from these overall types: Sri Lankan Tamils and Russian-speaking peoples in the former Soviet Union. In the case of Sri Lanka, a long and ultimately unsuccessful insurgency aimed to bring about a new state of Tamil Eelam as a homeland for the Tamils, and in the process of the conflict generated a large distant diaspora. In the postSoviet case, the disintegration of the USSR in the early 1990s saw the generation of contiguous diasporas as newly established borders in effect moved 'over the heads' of coethnics, dividing them among new states (Brubaker 1992). We suggest that this juxtaposition of cases evokes a perspective on conflict-induced diaspora different from what has gone before. We follow Robert Yin's suggestion that the case study method is appropriate when, among other things, the 'how' and 'why' questions are salient, and when the study is contemporary rather than (entirely) historical (Yin 2014: 14-17). We temper Yin's methodological suggestions with those of Dion (1998) on the possibilities of comparative case study approaches, including their application in conflict settings. In the case studies that we have selected it is the nature of the connection and disconnection between those inside and outside conflict-affected societies that is the point of comparison: the degree of congruence between the perceptions and aspirations of people in diaspora and the perspectives of those who remain in the country of origin has been a matter of intense controversy both during conflicts and after their end.

\section{Distant diasporas: The Sri Lankan Tamil case ${ }^{4}$}

The debate about the disjuncture between the diaspora and those at home has been particularly prominent in the case of the Sri Lankan Tamils, particularly in the wake of the defeat of the Liberation Tigers of Tamil Eelam (the LTTE or Tamil Tigers) in 2009. Our approach of disaggregating engagement among the three spheres helps to distinguish different orders of diaspora engagement in post-war Sri Lanka.

\footnotetext{
${ }^{4}$ This section draws on work with Cathrine Brun, and in particular Brun and Van Hear (2012).
} 
As far as the household and extended family sphere is concerned, remittances and other financial transfers are not surprisingly among the most significant forms of contributions made by the diaspora, and have continued to be so since the end of the war. Remittances are used to support living expenses, schooling, housing and sometimes small businesses. Remittances and practical assistance from family members in the diaspora also enable households to send other family members abroad: loans taken out to fund the migration are repaid through remittances. Many families with a member working abroad have invested in rebuilding their war-damaged homes, while wealthier exiles have renovated and rented out their houses as a source of additional income for themselves and their families. Others in the diaspora have begun to make investments in businesses, such as farms and guest houses, with the hope of returning to run them in the future. Beyond the financial, during the cease fire and after the war, diaspora members have been able to visit their former villages for weddings, funerals, other life course events, and religious festivals. In the case of Sri Lankan Tamil transnational households and extended families, these kinds of connections are as strong as ever, the more so now that, since the end of the war, physical (as opposed to virtual) linkages are more feasible.

In contrast to the continued and intense engagement of the diaspora in the household sphere following the end of the war, a pattern of fragmented diaspora engagement now obtains in the known community sphere - in the UK setting at least. Rather few Sri Lankan Tamils seem to be active members of diaspora associations, and most say that they prefer to make contributions on an occasional basis towards humanitarian, educational, health and livelihood projects. Religious institutions play an important mediating role, by channelling financial contributions from the diaspora through temples, churches and mosques. Many of these forms of engagement, which might appear to be organised through formal institutions, are actually reliant on informal networks which are created and sustained mostly (but not only) through these institutions. Since the end of the war scepticism has grown towards contributing through more formal organisations and contributions are instead channelled through informal networks of kin and friends. Often these are transferred to families, individuals in need, or to schools with which an individual might have a particular affiliation: indeed old school associations remain one of the few enduring 
arenas of active associational activity, with one's 'batch' (or cohort) a particular source of affinity.

As for the imagined community sphere, a number of groupings could be identified in the diasporic political field following the defeat of the LTTE in Sri Lanka in May 2009, reflecting different strands of thinking and ideology. One such grouping was the LTTE 'old guard', the rump of the LTTE which included the remnants of the organisation, who had got out before the endgame in Sri Lanka, or were already outside the country. Related to but distinct from this grouping is what might be called the 'LTTE legacy' or 'LTTE heritage'. Many of these were younger generation activists, who came to the fore during the large scale mobilisations of 2009 and 2010 in protest at the atrocities committed at the end of the war, and at the incarceration of civilians in large camps afterwards. More liberal and democratic than the hard core rump, they promoted a more moderate nationalism. Meanwhile, there was also a modest resurgence outside LTTE circles of more open discussion of possible ways forward, with various fora emerging which reached out with varying success to some of the new younger activists, and even to some sympathetic Sinhalese and Muslims. ${ }^{5}$ These were the main activist fractions. The Tamil diaspora population at large varied in its orientation, from enthusiastic to passive or grudging support for one or other of these positions - or none of them.

Several significant institutional initiatives emerged from mid-2009, as the implications of the defeat of the LTTE sank in among the diaspora. First, the Global Tamil Forum (GTF) was set up as an umbrella grouping for national level Tamil groupings, including the British Tamil Forum, the Canadian Tamil Congress, and similar French, Australian, Norwegian and other national groupings. The GTF held a successful launch in February 2010 in the British parliament, attended by delegates from fifteen countries with significant Tamil diaspora populations and addressed by high profile British politicians. Second, a referendum reasserting the need for an independent Tamil homeland was held in most major diaspora locations from mid- 2009 to early 2010. In a process which monitors attested was well-run,

\footnotetext{
${ }^{5}$ According to the 2012 census, Sri Lanka's population of just over 20 million comprises a Sinhalese majority of around $75 \%, 15 \%$ Tamils, $9 \%$ Muslims, and other minorities.
} 
most of those who voted appeared to reaffirm the resolution and thereby the need for a separate state of Tamil Eelam. Third, there were moves to form a 'Transnational Government of Tamil Eelam' (TGTE). The TGTE's founding documents drew heavily on scholarly discourse on transnationalism and diaspora. The initiative was met with scepticism both among hardliners in the LTTE rump and among more liberal elements in the diaspora who saw it as an attempt to revive a defunct LTTE. In the event a number of the LTTE rump stood and were elected as representatives. Elections were held in early May 2010, and the inaugural meeting of the TGTE constituent assembly was held in transnational session in Philadelphia, London, Geneva and other diaspora constituencies in mid May 2010 (Brun and Van Hear 2012). Further transnational sessions have been held since.

However, as time passed after the defeat of the LTTE, scepticism increased about diaspora organisations such as the TGTE, GTF and BTF. Fewer diaspora Tamils continued to attend large scale events, such as the annual 'Heroes Day', a transnational commemoration of those killed during the war, held in most diaspora locations and largely orchestrated by the LTTE legacy and its supporters: in London these gatherings drew up to 15,000 attendees at their height. These perspectives evidence a shift away from the politically active high-point involving second and 1.5 generation Tamils in 2009-2010, and a contrast to the initial enthusiasm which accompanied the proliferation of political bodies and advocacy groups following the demise of the LTTE (Brun and Van Hear, 2012: 70-71).

All of this was reflected in widely differing views on the degree of convergence in perspectives between those in the diaspora and those in Sri Lanka, particularly on whether an independent Tamil state was possible or even desirable. An interview with Visuvanathan Rudrakumaran, Prime Minister of the TGTE (Azwer, 2011), sets out the position widely held by many in the diaspora:

The diaspora is an integrated part of the Tamil Nation. The Tamils living in the island and outside are one entity. As long as the Tamils living in the island do not have the political space to fully articulate their political aspirations, the diaspora living around the world in liberal democratic countries have to undertake that task. 
Critics of the LTTE in the diaspora took a very different position. Writing in the final stages of the war, a month before the military defeat of the LTTE in May 2009, Nirmala Rajasingam, a long-time activist who had left the LTTE and become highly critical of it, highlighted the disparity between the diaspora and those left in the conflict zones:

The huge demonstrations in the west that endorse the LTTE are in direct opposition to the waning popular support for the LTTE amongst Tamils in Sri Lanka itself. The eastern region of Sri Lanka where many Tamils live - and which has lost far more of its young people and children in this war than any other Tamil region - has largely abandoned support for an independent state. The Jaffna peninsula in the north has been largely uninvolved for more than a decade or so in the separatist cause; there, the vast majority of civilians have submitted to uneasy cohabitation with the army simply because amid available options, they prefer an absence of war. The LTTE's cynical and callous use of civilians for its war effort has also over the years undermined its status within the Tamil population in Sri Lanka (Rajasingham, 2009).

Such views were echoed by outside observers. One of the most comprehensive explorations of the Tamil diaspora in the wake of the defeat of the LTTE in May 2009 was by the International Crisis Group (ICG, 2010). The study suggested that the views of those in the diaspora and those in Sri Lanka were far apart:

Most Tamils abroad remain profoundly committed to Tamil Eelam, the existence of a separate state in Sri Lanka. This has widened the gap between the diaspora and Tamils in Sri Lanka. Most in the country are exhausted by decades of war and are more concerned with rebuilding their lives under difficult circumstances than in continuing the struggle for an independent state (International Crisis Group, 2010: i)

Others, often within the Tamil diaspora itself - particularly in cyberspace - argued that this disconnection has been overstated. Providing a usefully nuanced understanding portrayal of post-war Tamil transnational politics, Vimalarajah and Cheran (2010) underlined the social and political cleavages within the diaspora, maintaining the lack of complete 
correspondence between diaspora politics and those of the LTTE. In short, support for Tamil nationalism and for the LTTE were (and are) not coterminous. This implied greater convergence between some members of the diaspora and some of those at home, and greater divergence between other members of both groups. It was hardly surprising, they suggested, that Tamils in Sri Lanka were keeping their heads down in the context of government triumphalism and the government's 'one nation, one country' narrative:

The politically active Tamil diaspora community reflect the same cleavages, political and social divisions that exist in Sri Lanka and cannot be disassociated from that context ... the main demarcation lines are no longer between those who are traditionally viewed as pro-LTTE and anti-LTTE but rather within the Tamil nationalist movement between those who call for a pragmatic approach and those who argue for a principled approach (Vimalarajah and Cheran, 2010: 6 \& 30).

As this often vigorous debate shows, that there is such disjuncture is often strongly contested by diaspora groups themselves. As we have argued, one way of addressing this question is to disaggregate different forms and spheres of diaspora engagement along the lines we have proposed. In the next section we continue this line of analysis in what we have termed contiguous diasporas.

\section{Contiguous diasporas: The Russian successor states}

We do not assign an inflated theoretical weight to the idea of 'contiguous diasporas': rather we use it to highlight the fact that many contemporary flashpoints are found where coethnics or co-religionists are separated by a national border. We are thinking of Russian and Russian-speaking minorities in the Soviet successor states and conflicts like the RussianGeorgian war of August 2008 (Europe's first war of the twenty-first century), the invasion (or, as Russian government describes it, the re-annexation) of Crimea, continuing conflict in eastern Ukraine, and the struggles over 'citizenship issues' (a phrase we will deconstruct) in Latvia, Estonia and Kyrgyzstan (see Brubaker 1992 for an early analysis). Beyond the Soviet successor states, the tangled events in Kosovo, South Sudan and now in Iraq-KurdistanSyria-Turkey and the so-called Islamic State (IS), are also connected to the existence of 
contiguous diasporas. As noted above, the distinction between a contiguous and distant diaspora resembles the distinctions drawn elsewhere between the 'near' and 'wider' diaspora (Van Hear, 2006), and the 'near abroad' and those 'far away' from conflict (Kaldor, 2001). Discussion of the Russian 'imperial diaspora' and the concept of a 'stranded minority' are also complementary (Cohen, 1997: 190-1). Kaldor (2001: 85) puts it this way:

There are two types of diaspora. On the one hand there are minorities living in the near abroad, fearful of their vulnerability to local nationalisms and often more extreme than those living on home territory. ... On the other hand, there are disaffected groups living far away, often in the new melting pot nations, who find solace in fantasies about their origins which are often far removed from reality.

It is not that important to settle the terminology used to describe contiguous diasporas; rather we need to address the question whether we can find a particular cluster of characteristics that marks the relationship between diasporas and conflict. The answer is 'yes', in each of the three spheres of engagement we have delineated, though the Russophones in Latvia exhibit a particularly complex case.

In the household or extended family sphere, contiguity produces very practical and prosaic advantages. These are not the archetypical 'Skype families', who sustain intimate personal contact through telephony and occasional family visits. Rather, to take the case of Russians in the Ukraine, there is continuous cross-border movement for family, educational or professional purposes. At the household or extended family level, it is common to find transnational families, split generationally or in terms of their level of consanguinity, leaving in search of educational or work opportunities. After the 1990s, the dominant nationalist forces in Soviet successor states pressed for a stronger sense of civic engagement and, in particular, enacted a number of restrictions on holding dual nationality that especially affected the Russian and Russophone families. This incomplete, but threatened, rupture of taken-for-granted transnational family practices eventually created the sense of threat or anxiety that spilled into a wider 'co-ethnic' solidarity. We place inverted commas around the 
expression 'co-ethnic' to indicate that Russian-speakers were not necessarily of Russian descent.

While transnational family life was somewhat disturbed, at the associational or known community level, it is important to bear in mind that the Russian-speaking minority in the 'near abroad' is often rather large. In the Ukraine the Russian population numbered well over 8 million before recent events, and in many places it is dominant. Life in a Russian leitmotif goes on - not always without challenge - in schools, neighbourhoods, parks, shops, churches and in many political settings. Given the former integration of the country into the Soviet Union, it is not perhaps surprising that Russian is widely spoken. Indeed at independence there were as many Russophones and Ukrainophones, while similar proportions used these languages on a daily basis (Shevel, 2002: 396). What is perhaps surprising is that, despite the acceptance by many parents that Ukrainian would increasingly become the language of 'politics and social advancement' on the Crimean peninsula, Shevel (2002: 404) reported in the early 2000s: 'Ukrainian schooling is all but unavailable. Only four of 583 schools on the peninsula provide instruction in Ukrainian; 98 percent of schoolchildren are educated in Russian'. It was within this problematic nexus between a frequently-expressed desire for civic engagement with the new polity and the continuity of Soviet and Russian social institutions that conflict was to erupt.

Before discussing the imagined community sphere, we need to provide some basic information. Of the 162 million Russian-speakers worldwide, some 25 million live outside Russia, nearly all concentrated in the contiguous diasporas or 'the near abroad'. In addition to Crimea and Ukraine, there are significant concentrations in Belarus, Kazakhstan and Kyrgyzstan (where Russian remains an official language) and in the Baltic states, where its status was derecognised after independence. The Russian language has been re-established in the breakaway republics of Abkhazia, South Ossetia and Transnistria - though none of these entities, we should add, has been recognized by the UN. The last three cases have been tellingly described as sites of 'frozen conflict' - i.e. few of the players are happy with the outcome, but none wishes to risk the consequences of intervention or further intervention. It is difficult to predict the final disposition of forces in Eastern Ukraine, but it is more than possible, as in the breakaway republics noted above, that the Donetsk People's 
Republic (declared in 2014) and other enclaves will also become Russophone frozen-conflict zones.

In the case of the Russian contiguous diaspora, there were many Russophones who simply ignored the independence of countries like Georgia, Ukraine and Latvia. Sheval (2013: 1), for example, refers to 'the large Russian minority in the east and south of Ukraine, and the continued scepticism and even downright non-acceptance of Ukrainian independence by many in Russia'. In the Soviet period, 'socialist internationalism' was the order of the day, an ideology which, of course, masked the imperial-like movements of settlers and armed personnel to the 'near abroad'. In the post-Soviet period, some of this rhetoric survives the Russian TV channel, Russia Today, alludes constantly to the 'fascists in Kiev' and the 'ultra-nationalists' in the Baltic states. Similarly, in describing Russian involvement in Crimean politics five years before the annexation, Mizrokhi (2009: 8) maintains that there is 'a residual feeling among certain Russian politicians that Crimea is a historic and integral part of Russia'. This perception of a wide imagined community was, she suggests, 'most pronounced among Russian communists and radical nationalists'. Immediately after the Russian intervention in Crimea in February-March 2014, this sentiment was echoed in an emotional speech by President Putin when he declared: 'In people's hearts and minds, Crimea has always been an integral part of Russia' (The Telegraph, 18 March 2014).

As this rhetoric hints, language issues are at the heart of the conflicts affecting the Russian contiguous diaspora and span the spheres of the known and imagined communities, as Schmid's (2008: 16) discussion of language tensions in Latvia indicates:

There is an unmistakable split in the language groups with respect to the importance of language issues. This split is apparent in attitudes toward the education reform, introducing Russian as a second language and the degree to which the two ethno-linguistic groups believe their language and culture are endangered. Many Latvians feel a sense of isolation and as a threatened group within their own country. Part of this isolation and sense of threat is related to 
historical factors, asymmetrical bilingualism, and the relative strength of Russian in comparison to Latvian.

Despite the apparent salience of language to conflict in this and many other accounts, one of the leading scholars in the field, having subjected a comprehensive data base to a sophisticated analysis, failed to find a strong association between competing language claims and conflict across a wide range of countries, arguing indeed the counter-thesis that competitive language claims are generally peacefully accommodated (Laitin, 2000). In addressing this anomaly, we hope to explain some of the dynamics of contemporary conflicts in the Russian diaspora.

First, despite his extensive comparative analysis, Laitin's data and outlook have failed to move beyond the national to the transnational level. In the case of the Russian contiguous diaspora, language spans the total imagined Russophone community. The Soviet Union encouraged 'internationalism', which in practice often meant that Russian soldiers were posted to various barracks in a number of countries in the 'near abroad', their families commonly moving with them.

The case of Latvia presents particular in challenges as one tries to navigate the converging and conflicting influences of language, ethnicity, nation and diaspora in the construction of a post-Soviet state. As Dzenovska (2014) explains:

The post-Soviet citizenship law in Latvia is based on the juridical stance that the post-Soviet Latvian state is a restoration of the pre-Soviet state. Thus, in order to be included in the body of citizenry, residents had to prove their kinship to the pre-war body of citizenry (which was multi-ethnic). This effectively excluded those who came during the Soviet period. Soviet-era incomers were asked to naturalise and placed in the category of 'resident non-citizens'. A language test was one aspect of the naturalisation test. Others included [a knowledge of Latvian] history and a residency requirement.

The effect of this ruling was that some 300,000 fell into the category of 'resident noncitizens'. Some, mainly older, residents simply could not pass the language test, but a 
significant group resisted the demands to naturalise - because they felt emotionally connected to the Soviet period, ethnically connected to Russia or indignant that they were, in effect, asked to prove their loyalty to the new state. Those who were offended included Russophones who were born and raised in Latvia, and who had worked there all their lives (Dzenovska, 2014).

We have already suggested that we need to be attentive to internal differentiation within diasporas on class, ethnic, generational and gender lines. Dzenovska (forthcoming) goes much further in suggesting that residents in the country who could not claim a pre-Soviet Latvian identity can be seen as a 'multitude'. She writes, 'Latvian intellectuals, the public and the emerging political elites were united in their belief that a unified and loyal nationrather than a messy post-Soviet multitude whose views could not be known or fully trustedwas needed to secure independence'. ${ }^{6}$ This multitude, this assemblage of minorities - call it what we will - then becomes the object of competitive claims for allegiance. 'The postSoviet Russian state and the post-Soviet Latvian state compete to make ethnic and national subjects out of this multitude: the Latvian state tries to make citizens and national minorities, whereas the Russian state tries to make co-ethnics and diaspora' (Dzenovska, 2014).

These struggles at the level of the nation are nested in international geopolitical struggles that could trigger Russian intervention in support of Russophones in Latvia (and elsewhere). As we write (2015), President Obama is weakened politically and in any case is unlikely to want to engage in another foreign adventure. Without US support, NATO is impotent. The Eurozone is economically fragile and Germany is crucially dependent on Russian gas and oil. Moreover, Putin seems perfectly capable of exercising force, or the threat of force. Despite these elements, we might advance a modified version of the Laitin thesis, taking into account Dzenovska's observations. If the Russian Federation is to intervene in Latvia, it will not (unlike in Crimea) find a completely unified and allied diaspora. Some of the 'non-

\footnotetext{
${ }^{6}$ Such groups, and Dzenovska herself, use 'multitude' in a pejorative way, echoing Hobbes's distinction in De Cive between a 'multitude' and a 'people'. Hardt and Negri (2004) suggest a more positive connotation, seemingly maintaining that a multitude can be seen as a new revolutionary subject, succeeding Marx's proletariat. However, it is difficult to know what exactly they are arguing as their work is notoriously vague.
} 
citizens' of an older generation might be responsive to Russian blandishments. The younger generation, by contrast, wants to learn Latvian (and English), acquire Latvian citizenship and find their future, notwithstanding the EU's current difficulties, in Western Europe. In short, whatever Putin's intentions in Latvia, he faces a complex, and not entirely sympathetic, community of Russophones - not entirely national, ethnically singular or diasporic.

\section{Conclusion}

Taking two contrasting cases of 'distant' and 'contiguous' diasporas, we have used our 'three spheres' trisection to examine different forms of connection and disengagement: as we have noted, the spheres are not always in harmony with one another.

There may be strong and sustained engagement in the first sphere - that of the transnational household and extended family, a largely private sphere. As we have seen this includes transfers of remittances and other resources, as well as participation in life course events such as weddings and funerals. Visits, phone calls and marriages cement dense and continuous forms of household engagement. This is particularly true in the case of contiguous diasporas where cross-border movements may be easier and cheaper than within-country mobility.

There tends to be weaker and more intermittent engagement in the second sphere - that of the 'known community'- where advancement is the holy grail for post-conflict recovery and development actors. Engagement here includes involvement in home town and home village associations, old school associations, and other community-based organizations. In the case of both distant and contiguous diasporas, cross-border participation in festivals, religious ceremonies, sporting events and trade make the known community a transnational one. However, associational life can often lead away from diasporic leanings to more local forms of civic engagement, as in the case of Latvian Russophones. On the ground, accomplishments often turn out to be much weaker than those sometimes claimed by distant diasporans.

Engagement in the wider 'imagined community', a more public sphere, can be strong but is often ephemeral. It includes involvement in political movements, support for insurgent 
groups, and debate in cyberspace on social, political and cultural matters. Here engagement often cuts both ways: it can result in reconciliation and recovery, or it can reignite or prolong conflict. The imagined community can be evoked or activated both by the diasporas and the state or homeland from which it emanates. Again, there may be incongruity between the community imagined by the origin state and that imagined in the state of settlement.

In this paper we have drawn on research on distant and contiguous diasporas to explore ways in which these different spheres interrelate and shift in importance over time in conditions of conflict, tension, displacement and (forced) immobility. Moreover these different forms and levels of engagement generate varying levels of demand on diasporan households: they have to balance the demands of their own livelihoods and futures (most importantly perhaps education of their children), those in other destination and transit countries, and those left at home, or in neighbouring countries of first refuge (Van Hear, 2006a, 2006b; Lindley, 2010). There is thus a 'portfolio' of obligations in the diaspora, which may become unsustainable and debilitating, particularly if those in the diaspora have low, precarious incomes, as is often the case. In the case of contiguous diasporas, they may find likewise themselves cross-pressured, asked daily to speak the language or show affinity to their places of origin, their ethnicity or to a virtual imaginary community invented by powerful political actors.

Differences of wealth, resources, social capital and class shape the capacity and level of support that can be offered and thus the circulation of resources among these different sites. This brings us back to the capacity and inclination - the disposition - of the diaspora to engage in conflict settings, which is in turn linked to the kind of recovery and development that might emerge as a result of diaspora engagement. Diaspora connections may be vital in sustaining societies in upheaval or conflict, and have the potential for assisting such societies once conflict lessens. Building on such potential involves understanding that the return of some members of a household or community to a 'post-conflict' society may be predicated on others staying abroad. That way the viability or durability of the return would be enhanced: by sending money home for example, those abroad may help to set up or sustain livelihoods established by returnees during start-up periods or during hard times. A 
sustainable livelihood may then be established as the basis for subsequent returns of the displaced. At the same time, as has been suggested above, the deployment of transnational connections in such ways is predicated on some elements of the diaspora attaining reasonably secure residence in the place of exile.

In a way, diaspora engagement in the three spheres can be seen as a transnational welfare system or social security safety net to help people cope with adversity - what may be called a sustaining or conserving function -- and/or a source of support for progressive or retrogressive change in the homeland - in other words a transformative function (Van Hear 2002). Much depends on the degree and nature of connection or disconnection between the diaspora and those that have been left or who have stayed at home. As we have seen, the nature of this relationship varies and is often a matter of dispute. This paper has offered a framework that takes account of different levels or spheres of engagement, which may help better to understand the relationship between those diasporas and home in conflict settings.

\section{Acknowledgements}

We would like to thank Dace Dzenovska for her extensive comments on this paper and apologise to her to not being able to respond fully to all her arguments. Nicholas Van Hear would like to thank Cathrine Brun, Leslie Fesenmyer and Giulia Liberatore for contributions to the analysis of the Sri Lanka case, as well as Sri Lankan research assistants who gathered material in London and Sri Lanka. As well as the Leverhulme Trust support for the Oxford Diasporas Programme, Nicholas Van Hear would like to thank Canada's International Development Research Centre for its support. 


\section{References}

Adamson, F. (2002) Mobilizing for the transformation of home: politicized identities and transnational practices, in New approaches to migration: transnational communities and the transformation of home, K. Koser and N. Al-Ali (eds.) (London: Routledge), pp. 155-68.

Adamson, F. (2005) Globalisation, transnational political mobilisation, and networks of violence, Cambridge Review of International Affairs, 18(1), pp. 31-49.

Adamson, F. (2013) Mechanisms of Diaspora Mobilization and the Transnationalization of Civil War, in J. Checkel, ed: Transnational Dynamics of Civil War. (Cambridge, UK: Cambridge University Press: pp. 63-88).

Adamson, F. (2012) Constructing the Diaspora: Diaspora Identity Politics and Transnational Social Movements, in T. Lyons and P. Mandaville, eds: Politics from Afar: Transnational Diasporas and Networks. (New York: Columbia University Press).

Al-Ali, N., Black, R. and Koser, K. (2001) The limits to transnationalism: Bosnian and Eritrean refugees in Europe as emerging transnational communities, Ethnic and Racial Studies, 24(4), pp. 578-600.

Anderson, B. (1983/1991) Imagined communities: reflections on the origin and spread of nationalism, (London: Verso).

Anderson, B. (1992) Long-distance nationalism: world capitalism and the rise of identity politics, Amsterdam: Centre for Asian Studies.

Azwer, M. (2011) Interview with 'prime minister' of Tamil diaspora's Transnational Government, Sunday Leader, Colombo, 23 March 2011.

Brinkerhoff, J. (2011) Diasporas and conflict societies: conflict entrepreneurs, competing interests or contributors to stability and development? Conflict, Security \& Development, 11, (2), pp. 115-143. 
Brubaker, W. Rogers (1992) Citizenship struggles in Soviet successor states, International Migration Review, 26(2), pp. 269-91.

Brubaker, W. Rogers (2005) 'The “diaspora” diaspora', Ethnic and Racial Studies 28 (1), pp 1-19.

Brun, C. and Van Hear, N. (2012) Between the local and the diasporic: the shifting centre of gravity in war-torn Sri Lanka's transnational politics. Contemporary South Asia, 20(1), pp. $61-75$.

Cochrane, F., B. Baser and A. Swain (2009) 'Home Thoughts from Abroad: Diasporas and PeaceBuilding in Northern Ireland and Sri Lanka', Studies in Conflict \& Terrorism, 32 (8), pp. 681704.

Cohen, R. and Rai, S. (2000) (eds.) Global social movements, (London: Continuum).

Collier, P. (2000) Economic causes of civil conflict and their implications for policy, (Washington DC, World Bank).

Collier, P. and Hoeffler, A. (2004). Greed and grievance in civil war, Oxford Economic Papers, 56: pp. 563-95.

Dion, D. (1998) Evidence and inference in the comparative case study, Comparative Politics, 30, 2: $127-145$.

Dzenovska, D. (2014) Comment on this paper; private correspondence.

Dzenovska, D. (forthcoming) Complicit Becoming: Tolerance Work and Europeanization after Socialism Unpublished manuscript.

Duffield, M. (1996) The symphony of the damned: racial discourse, complex political emergencies and humanitarian aid, Disasters, 20(3), pp. 173-93.

(1998) Post-modern conflict: Warlords, post-adjustment states and private protection, Civil Wars, 1(1), pp. 65-102. 
------ (2001) Global governance and the New Wars: the merging of development and security, (London: Zed Books).

(2007) Development, Security and Unending War: Governing the World of Peoples, (Cambridge: Polity Press).

Fitzgerald, V., Stewart, F. and Associates (2000) War and underdevelopment: the economic and social consequences of conflict, (Oxford: Oxford University Press).

Fitzgerald, V., F. Stewart, and R. Venugopal (2006) Globalisation, violent conflict and selfdetermination, (Basingstoke: Palgrave Macmillan).

Gamlen, A. (2014) Diaspora Institutions and Diaspora Governance, International Migration Review, 48: S180-S217.

Hardt, M. and Negri, A. 2004. Multitude, (New York: The Penguin Press).

Harpviken, K. (2008) From 'refugee warriors' to 'returnee warriors', Global Migration and Transnational Politics Working Paper No 5, Fairfax, VA: George Mason University.

Harpviken, K. and Lischer, S. (2013) 'Refugee Militancy in Exile and Upon Return in Afghanistan and Rwanda', in J. Checkel (ed.): Transnational Dynamics of Civil War, Cambridge: Cambridge University Press: 89-119.

International Crisis Group (2010) The Sri Lankan diaspora after the LTTE, Colombo/Brussels: Asia Report No 186.

Kaldor, M. (2012) New and Old Wars: Organised Violence in a Global Era, (Cambridge: Polity Press).

Kapur, D. (2007) The Janus face of diasporas, in B J Merz, L Chen and P Geithner eds Diaporas and development, (Cambridge, MA: Harvard University Press), pp. 89-118.

Keen, D. (1998) The Economic Functions of Violence in Civil Wars, Adelphi paper 320, (London: Routledge). 
Koinova, M. (2012) 'Four Types of Diaspora Mobilization: Albanian Diaspora Activism for Kosovo Independence in the US and the UK', Foreign Policy Analysis, 9 (4), pp. 433-453.

Laitin, D. (2000) Language conflict and violence: the straw that strengthens the camel's back, European Journal of Sociology, 41(10), pp. 97-137.

Lindley, A. (2010) The early morning phone call: Somali refugees' remittances, (Oxford: Berghahn).

Lyons, T. (2007) Conflict-generated diasporas and transnational politics in Ethiopia, Conflict, Security \& Development , 7 (4), pp. 529-549.

Lyons, T. and P. Mandaville, eds. (2011) Politics From Afar: Transnational Diasporas and Networks, (New York: Columbia University Press).

Mizrokhi, E. (2009) Russian 'separatism' in Crimea and NATO: Ukraine's big hope, Russia's grand gamble, Quebec City: Institut québécois des hautes études internationals.

Orjuela, C. (2003). War, peace and the Sri Lankan diaspora, in Diasporas, armed conflicts, and peacebuilding in their homelands, A. Swain (ed.), (Uppsala: Uppsala University Press).

Reno, W. (1998) Warlord Politics and African States, (Boulder, CO: Lynne Rienner).

Richards, P. (1996) Fighting for the Rain Forest. War, Youth \& Resources in Sierra Leone, (Oxford: James Currey).

Schmid, C. (2008) Latvia Ethnicity and language tensions in Latvia, Language Policy, 7, pp. 3-19.

Shain, Y. and Barth, A (2003) 'Diasporas and International Relations Theory', International Organization, 57, pp.449-479.

Sheffer, G. (2003) Diaspora Politics: At Home Abroad, (Cambridge: CUP).

Shevel, O. (2002) Nationality in Ukraine: some rules of engagement, East European Politics \& Societies, 16(2), pp. 386-413. 
Shevel, O. (2013) Ukraine: Country Report, European University Institute, (Florence: Robert Schuman Centre for Advanced Studies and EU Citizenship Observatory).

Sklair, L (2000) The transnational capitalist class, (Oxford: Wiley-Blackwell).

Smith, H. and Stares, P. B. (2007). Diasporas in conflict: peace-makers or peace-wreckers? (Tokyo: United Nations University).

Sökefeld, M. (2006) Mobilizing in transnational space: a social movement approach to the formation of diaspora, Global Networks, 6(3), pp. 265-84.

Van Hear, N. (2002) Sustaining societies under strain: remittances as a form of transnational exchange in Sri Lanka and Ghana, in New approaches to migration: transnational communities and the transformation of home, edited by K. Koser and N. Al-Ali, (London: Routledge), pp. 202-23.

Van Hear, N. (2006a) 'I went as far as my money would take me: conflict, forced migration and class, in Forced migration and global processes: a view from forced migration studies, eds F. Crepeau, D. Nakache and M. Collyer. (Lanham MA: Lexington/Rowman and Littlefield), pp. $125-58$.

Van Hear, N. (2006b) Refugees in diaspora: from durable solutions to transnational relations, Refuge, 23 (1), pp. 9-14.

Van Hear, N. (2009) 'The rise of refugee diasporas', Current History, 108, 717: 180-185.

Vimalarajah, L. and R. Cheran (2010), Empowering diasporas: the dynamics of post-war transnational Tamil politics. Berghof Occasional Paper 31. (Berlin: Berghof Conflict Research, Berghof Peace Support).

Yin, R. (2014) Case study research: design and methods, (London: Sage). 